\title{
Penyeleksian Siswa Partner Schulen Der Zukunft dengan Metode Weighted Product (WP) di SMAN 3 Tasikmalaya
}

\author{
Selection of Students Partner Schulen Der Zukunft \\ using Weighted Product Methods in SMAN 3 Tasikmalaya
}

\author{
Evi Dewi Sri Mulyani ${ }^{1}$, Asep Sugiharto ${ }^{2}$, Risal Agustian ${ }^{3}$ \\ ${ }^{1,2,3}$ STMIK Tasikmalaya \\ E-mail: *1 eviajadech@gmail.com, ${ }^{2}$ asepsugiharto@yahoo.com, ${ }^{3}$ risalagustian@gmail.com
}

\begin{abstract}
Abstrak
Proses seleksi dalam menentukan penerima beasiswa masih mengalami kendala. bahwasanya dari tahun ke tahun terdapat kenaikan peminat siswa untuk mengikuti program PASCH begitu pula kuota untuk penerima beasiswa pun terbatas dan dari tahun ke tahun menurun karena kebijakan dari pemerintah jerman sendiri disebabkan di tanggung oleh pemerintah jerman, dan kemampuan kompotensi yang dimiliki dari setiap siswa sangat tipis, menjadi kendala dan hambatan yang terdapat dalam proses penyeleksian siswa mengakibatkan keraguan dalam pengambilan keputusan yang memungkinkan terjadi kesalahan keputusan yang kurang tepat. Oleh karena itu perlu menerapkan metode pengambilan keputusan berbasis komputer, untuk memperketat, memperkuat, meminimalisir kesalahan, serta proses seleksi menjadi lebih efektif dan efisien. Penerapan metode banyak digunakan untuk membantu menyelesaikan masalah seleksi calon penerima beasiswa, ada beberapa metode yang dapat di gunakan dalam menyelesaikan kasus penyeleksian/perangkingan beasiswa untuk berangkat ke jerman, salah satunya metode yang diterapkan adalah Weighted Product (WP).
\end{abstract}

Kata Kunci - Sistem Penunjang Keputusan, Weighted Product, Penyeleksian Siswa.

\begin{abstract}
The selection process to determine the scholarship recipients are still having problems. that from year to year there is an increase interest of students to join the program Pasch so are quotas for scholarships is limited, and from year to year decline due to the policy of the German government itself is caused on the responsibility of the German government, and the ability of competency possessed of every student very thin, the constraints and obstacles contained in the student selection process led to doubts in the decision making that allows an error occurred less appropriate decisions. Therefore it is necessary to apply a computer-based decision-making methods, to tighten, strengthen, minimize errors, and the selection process becomes more effective and efficient. application of the method being used to help solve the problem of selection of the applicants, there are several methods that can be used in solving the case of the selection/perangkingan a scholarship to go to Germany, one of the methods applied are Weighted Product (WP).
\end{abstract}

Keywords - Decission Support System, Weighted Product, Students Exchange 


\section{PENDAHULUAN}

Penguasaan bahasa asing menjadi sebuah keharusan, karena bahasa asing berfungsi sebagai sarana berpikir, sarana pendukung pertumbuhan dan perkembangan ilmu pengetahuan dan teknologi selain itu bahasa berfungsi sebagai alat untuk mengekspresikan diri, untuk berkomunikasi, untuk mengadakan integrasi dan beradaptasi sosial dalam lingkungan atau situasi tertentu. Kemampuan menguasai bahasa asing mempunyai peranan sangat besar di bidang pendidikan, perkembangan ilmu pengetahuan, teknologi dan dunia kerja. [1] Begitu pun di dunia pendidikan penguasaan bahasa asing sudah di terapkan oleh sekolah di Indonesia salah satunya adalah bahasa jerman, pembelajaran bahasa Jerman di luar negeri membuka jendela menuju Jerman dan sekaligus memperkenalkan nilai-nilai sosial. Kementerian Luar Negeri Jerman meluncurkan (Partner Schulen Der Zukunft) (PASCH).

SMAN 3 Tasikmalaya merupakan salah satu yang terpilih menjadi mitra menuju masa depan dari tahun 2008 ,yang setiap tahun memberangkatkan siswa nya ke jerman untuk belajar mendalami bahasa dan budaya jerman selama 3 minggu, dalam hal ini sekolah harus menyeleksi siswa yang benar - benar layak untuk mendapatkan kesempatan berangkat ke jerman dengan beberapa kriteria yang harus dipenuhi yaitu nilai tes tulis ,nilai kemampuan bahasa jerman, nilai wawancara, nilai rapot, nilai pengetahuan budaya.Adapun kendala sesuai data yang ada sesuai hasil observasi dan wawancara dengan guru / koordinator program PASCH yaitu:

Tabel 1. Peminat Siswa dari periode 2009 sampai dengan 2015 untuk program Partner Schulen Der Zukunft

\begin{tabular}{|c|c|c|}
\hline Tahun Ajaran & $\begin{array}{c}\text { Peserta yang } \\
\text { Mengikuti Seleksi }\end{array}$ & Kuota Beasiswa \\
\hline $2009 / 2010$ & 90 Siswa & 4 \\
\hline $2010 / 2011$ & 147 Siswa & 8 \\
\hline $2011 / 2012$ & 116 Siswa & 3 \\
\hline $2012 / 2013$ & 144 Siswa & 3 \\
\hline $2013 / 2014$ & 154 Siswa & 3 \\
\hline $2014 / 2015$ & 173 Siswa & 3 \\
\hline $2015 / 2016$ & $?$ & 3 \\
\hline
\end{tabular}

Terlihat dalam Tabel 1 bahwa dari ke tahun terdapat kenaikan peminat siswa untuk mengikuti program PASCH begitu pula kuota untuk penerima beasiswa pun terbatas dan dari tahun ke tahun menurun karena biaya yang di tanggung oleh pemerintah jerman dan kemampuan kompotensi yang dimiliki dari setiap siswa sangat tipis, menjadi kendala dan hambatan yang terdapat dalam proses penyeleksian siswa mengakibatkan keraguan dalam pengambilan keputusan yang memungkinkan terjadi kesalahan keputusan yang kurang tepat.Peserta yang terpilih kadang jauh dari yang diharapkan karena peserta tersebut tidak memiliki kriteria yang layak bahkan ada yang mengundurkan diri setelah terpilih karena masih tergantung pada keputusan yang tidak pasti ,serta keterbatasan dari tenaga pengajar Bahasa Jerman hanya 3 orang sehingga dapat terjadinya kesalahan karena proses perekapan data memerlukan waktu yang lebih lama sedangkan tuntutan dari pemerintah Jerman pihak sekolah harus menentukan dengan cepat dan tepat untuk memutuskan peserta yang di terima atau berkesempatan untuk diberangkatkan ke Jerman untuk mewakili SMAN 3 Tasikmalaya.

Oleh karena itu perlu menerapkan metode pengambilan keputusan berbasis komputer, untuk memperketat, memperkuat, meminimalisir kesalahan, serta proses seleksi menjadi lebih efektif dan efisien. Penerapan metode banyak digunakan untuk membantu menyelesaikan masalah seleksi calon penerima beasiswa, ada beberapa metode yang dapat di gunakan dalam menyelesaikan kasus penyeleksian / perangkingan beasiswa untuk berangkat ke jerman, salah satunya metode yang diterapkan adalah Weighted Product (WP). Weighted Product adalah metode yang paling sederhana dari berbagai metode dalam sistem pendukung keputusan, yang 
penyelesaiannya dengan menggunakan perkalian untuk menghubungkan nilai atribut, dimana nilai harus dipangkatkan terlebih dahulu dengan bobot atribut yang bersangkutan. [2] Perangkingan dengan metode weighted product di pengaruhi oleh banyaknya kriteria, perbandingan tingkat kepentigan antar kriteria, dan pangkat bobot kriteria, hasil perangkingannya berdasarkan pada preferensi relatif yang terbesar sampai yang terkecil. Dengan metode Weighted Product ini, diharapkan proses seleksi calon siswa yang berangkat ke jerman akan lebih tepat, dan hasilnya bisa digunakan sebagai acuan dalam pengambilan keputusan secara tepat.

Penelitian yang sudah pernah dilakukan terkait dengan masalah penyeleksian, pengambilan keputusan dan metode Weighted Product diantaranya: Perancangan Sistem Pendukung Keputusan Seleksi Penerimaan Calon Bintara TNI AD Dengan Menggunakan Metode Weighted Product (Studi Kasus: Panitia Daerah Kodam I Bukit Barisan Medan).[3] Menurut penelitian tersebut bahwasanya Metode Weighted Product (WP) dapat membantu dalam mengambil keputusan untuk seleksi penerimaan calon bintara TNI AD sesuai dengan kriteriakriteria yang sudah ditentukan. Penerapan metode Weighted Product (WP) cukup mudah digunakan sebagai cara untuk melakukan penilaian pada seleksi penerimaan calon bintara TNI AD karena langka-langkah penyelesaiannya cukup sederhana. Perhitungan Weighted Product (WP) ada 3 tahap yaitu, penentuan nilai bobot $\mathrm{W}$, penentuan nilai vekor S, serta penentuan nilai vector V. Penelitian lainnya yaitu yang berjudul Sistem Pendukung Keputusan Penerimaan Pegawai Baru Pada Pt. Abadi Express (Tiki) Yogyakarta.[4] Berdasarkan pembahasan dan implementasi program yang mengacu pada rumusan masalah pada penelitian tersebut yaitu bagaimana merancang dan mengimplementasikan sebuah sistem pendukung keputusan untuk membantu memberikan keputusan pihak HRD perusahaan dalam menentukan penerimaan pegawai baru menggunakan metode weighted product, maka dapat di ambil kesimpulan bahwa metode Weighted Product ini dapat digunakan untuk mengolah data pelamar di TIKI untuk menjadi suatu alternatif keputusan dimana dapat membantu pihak HRD dalam mengambil keputusan untuk menentukan pegawai baru yang sesuai dengan kebutuhan perusahaan. Dan penelitian lainnya berjudul Penerapan Metode Weighted Product Model Untuk Seleksi Calon Karyawan. [5] Berdasarkan penelitian tersebut dapat disimpulkan bahwa sistem pendukung keputusan dengan metode weighted Product rekrutmen karyawan produksi pada PT. Ploss Asia Semarang dapat membantu dalam memberi rekomendasi dan pertimbangan dalam menentukan pelamar mana yang akan diterima dari hasil test yang telah diolah dalam sistem tersebut. Dengan berhasilnya dibuat sistem pendukung keputusan rekrutmen karyawan produksi ini berarti membutikan bahwa metode WP yang diterapkan dalam sistem berhasil di implementasikan dan telah dibuktikan pada saat tahap pengujian sistem. Pada penelitian ini permasalahan yang terjadi adalah poses perekapan data dan perhitungan hasil penyeleksian memerlukan waktu yang lama dan sering terjadinya kekeliruan hasil perhitungan dalam penyeleksian siswa karena di nilai tidak objektif.

\section{METODE PENELITIAN}

Dalam penelitian ini digunakan metode penelitian tindakan atau sering di sebut metode action research. Pengertian dari metode action research adalah kegiatan dan atau tindakan perbaikan sesuatu yang perencanaan, pelaksanaan, dan evaluasinya digarap secara sistematik sehingga validitas dan reliabilitasnya mencapai tingkatan riset. Action research juga merupakan proses yang mencakup siklus aksi, yang mendasarkan pada refleksi, umpan balik (feedback), bukti (evidence), dan evaluasi atas aksi sebelumnya dan situasi sekarang. Penelitian tindakan bertujuan untuk memperoleh pengetahuan untuk situasi atau sasaran khusus dari pada pengetahuan yang secara ilmiah tergeneralisasi. Adapun kerangka berpikir metode action research dalam dilihat pada Gambar 1. 


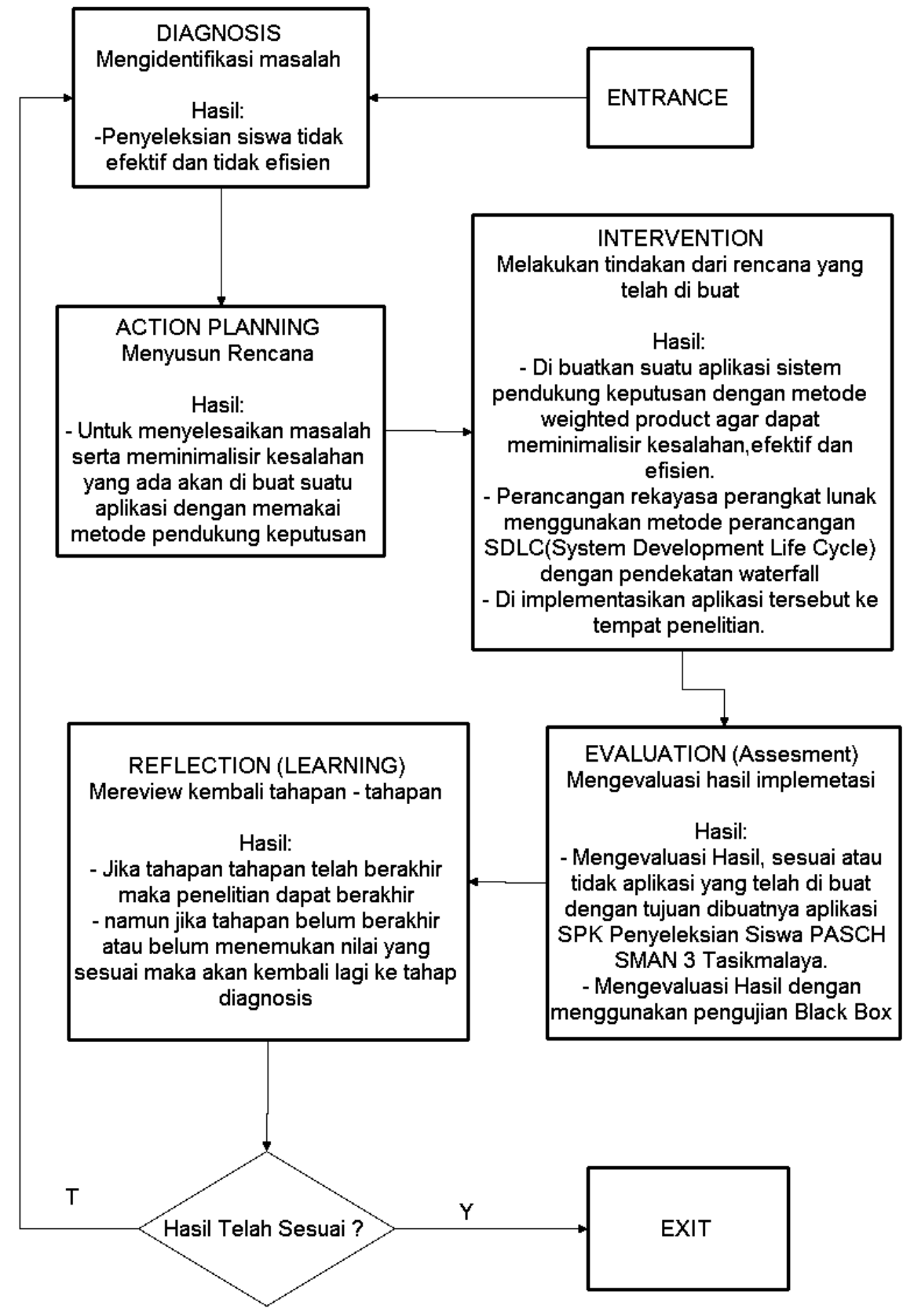

Gambar 1. Kerangka berpikir siklus action research 


\section{HASIL DAN PEMBAHASAN}

Pada penelitian ini dilakukan tahapan analisis pemecahan masalah dengan metode weighted product sebagai berikut.

\subsection{Menentukan Kriteria-Kriteria yang Akan Dijadikan Acuan dalam Pengambilan Keputusan}

Untuk penyelesaiannya masalah diperlukan kriteria-kriteria dan bobot dalam melakukan perhitungan sehingga akan diperoleh alternatif terbaik, seperti disajikan pada Tabel 2.

Tabel 2. Kriteria Penyeleksian

\begin{tabular}{|c|l|}
\hline Kode Kriteria & \multicolumn{1}{|c|}{ Kriteria } \\
\hline C1 & Nilai Tes Tulis \\
\hline C2 & Nilai Kemampuan Berbahasa Jerman \\
\hline C3 & Nilai Wawancara \\
\hline C4 & Nilai Rapot \\
\hline C5 & Nilai Pengetahuan Budaya \\
\hline
\end{tabular}

\subsection{Dilakukan Pembobotan Awal pada Setiap Kriteria}

Penentuan bobot berdasarkan nilai tingkat kepentingan masing-masing kriteria, tingkat kepentingan setiap kriteria dinilai dengan 1 sampai 5. Tingkat kepentingan dapat dilihat pada Tabel 3.

Tabel 3. Tingkat Kepentingan

\begin{tabular}{|l|c|}
\hline \multicolumn{1}{|c|}{ Tingkat Kepentingan } & Nilai \\
\hline Sangat Tinggi & 5 \\
\hline Tinggi & 4 \\
\hline Cukup & 3 \\
\hline Rendah & 2 \\
\hline Sangat Rendah & 1 \\
\hline
\end{tabular}

Nilai bobot atau bobot awal $(W)$ masing-masing kriteria telah ditentukan oleh pihak sekolah pada Tabel 4.

Tabel 4. Pembobotan Kriteria

\begin{tabular}{|c|c|}
\hline Kode & Bobot \\
\hline C1 & 4 \\
\hline C2 & 5 \\
\hline C 3 & 5 \\
\hline C 4 & 3 \\
\hline C5 & 4 \\
\hline
\end{tabular}

\subsection{Menentukan Kriteria yang Bernilai Keuntungan dan Biaya}

Setelah ditentukan kriteria dan bobot, di cari kriteria mana yang bernilai keuntungan dan biaya. Jika bernilai keuntungan maka nilai atribut tersebut tetap (positif) dan jika bernilai biaya akan berubah menjadi negative. Pada contoh kasus diatas semua atribut bernilai positif. Rumus Weighted Product:

a. Perbaikan Bobot Perkriteria

$$
\mathbf{W j}=\frac{\mathbf{w j}}{\sum \mathbf{w j}} \ldots \text { (1) }
$$


b. Perhitungan Vektor $\mathrm{S}$

$$
S_{i}=\pi_{j=1}^{n} X_{i j}{ }^{w j}
$$

c. Perhitungan Vektor V (Hasil Akhir)

$$
V=\frac{\pi_{j=1}^{n} X \mathbf{X j j} w \mathbf{j}}{\pi_{\mathrm{j}=1}^{n}(X \mathbf{j} *) \mathbf{w j}} \ldots(3)
$$

Dalam perhitungan metode weighted product digunakan teknik galat pembulatan untuk proses pembulatan hasil dari setiap perhitungan karena pembulatan bilangan sering dilakukan di dalam proses kumputasi, pembulan ini dimaksudkan untuk mengurangi atau membatasi cacah digit pada suatu nilai hampiran dengan cara membuang beberapa digit terakhir. [6]

Pembulatan yang digunakan adalah 7 angka di belakang koma guna meminimalisir nilai yang sama. Seperti contoh berikut ini: 0,1666666666666 dibulatkan menjadi 0,1666667.

\subsection{Perbaikan Bobot}

Setelah mendapatkan nilai bobot pada masing-masing kriteria maka dilakukan Perbaikan Bobot dari Nilai bobot awal.

Dengan rumus:

$$
\begin{aligned}
& \mathrm{W} 1=\frac{4}{4+5+5+3+4}=0.1904762 \\
& \mathrm{~W} 2=\frac{5}{4+5+5+3+4}=0.2380952 \\
& \mathrm{~W} 3=\frac{5}{4+5+5+3+4}=0.2380952 \\
& \mathrm{~W} 4=\frac{3}{4+5+5+3+4}=0.1428571 \\
& \mathrm{~W} 5=\frac{4}{4+5+5+3+4}=0.1904762
\end{aligned}
$$

\subsection{Perhitungan Nilai Vektor $(S)$}

Setelah dilakukan perbaikan bobot dilakukan perhitungan nilai vector (S) dengan data penilaian pada Tabel 5 .

Tabel 5. Data Penilaian Siswa Periode 2011 / 2012

\begin{tabular}{|l|l|l|l|l|l|}
\hline \multirow{2}{*}{ Alternative } & \multicolumn{5}{|c|}{ Kode Kriteria } \\
\cline { 2 - 7 } & $\mathrm{C} 1$ & $\mathrm{C} 2$ & $\mathrm{C} 3$ & $\mathrm{C} 4$ & $\mathrm{C} 5$ \\
\hline A1 & 80 & 87,5 & 100 & 82 & 60 \\
\hline A2 & 80 & 75 & 50 & 79,5 & 80 \\
\hline A3 & 100 & 87,5 & 75 & 85 & 60 \\
\hline A4 & 93,33 & 87,5 & 50 & 82,42 & 80 \\
\hline$\ldots \ldots$ & $\ldots \ldots$ & $\ldots \ldots$ & $\ldots \ldots$ & $\ldots \ldots$ & $\ldots \ldots$ \\
\hline A90 & 86,67 & 75 & 100 & 82,33 & 60 \\
\hline
\end{tabular}

Perhitungan nilai vector $(\mathrm{S})$ dengan rumus:

$$
\begin{aligned}
& \text { S1 }=\left(80^{0.1904762}\right)\left(87,5^{0.2380952}\right)\left(100^{0.2380952}\right)\left(82^{0.1428571}\right)\left(60^{0.1904762}\right)=81,8774167 \\
& \text { S2 }=\left(80^{0.1904762}\right)\left(75^{0.2380952}\right)\left(50^{0.2380952}\right)\left(79,5^{0.1428571}\right)\left(80^{0.1904762}\right)=70,3764743 \\
& \text { S3 }=\left(100^{0.1904762}\right)\left(87,5^{0.2380952}\right)\left(75^{0.2380952}\right)\left(85^{0.1428571}\right)\left(60^{0.1904762}\right)=80,1872205 \\
& \text { S4 }=\left(93,33^{0.1904762}\right)\left(87,5^{0.2380952}\right)\left(50^{0.2380952}\right)\left(82,42^{0.1428571}\right)\left(80^{0.1904762}\right)=75,5707893 \\
& \text { S5 }=\left(86,67^{0.1904762}\right)\left(62,5^{0.2380952}\right)\left(100^{0.2380952}\right)\left(83,67^{0.1428571}\right)\left(80^{0.1904762}\right)=81,2914701 \\
& \text { S4 }=\left(93,33^{0.1904762}\right)\left(87,5^{0.2380952}\right)\left(50^{0.2380952}\right)\left(82,42^{0.1428571}\right)\left(80^{0.1904762}\right)=75,5707893
\end{aligned}
$$


Citec Journal, Vol. 3, No. 4, Agustus 2016 - Oktober 2016 ISSN: $2460-4259$

Untuk nilai S11 sampai dengan S90 dihasilkan dengan perhitungan yang sama, sehingga akan mendapatkan Nilai S1 sampai dengan S90 pada Tabel 6.

Tabel 6. Nilai Preferensi Vektor S

\begin{tabular}{|l|l|}
\hline Preferensi alternatif & Nilai Vektor S \\
\hline S1 & 81,8774167 \\
\hline S2 & 70,3764743 \\
\hline S3 & 80,1872205 \\
\hline S4 & 75,5707893 \\
\hline$\ldots \ldots$ & $\ldots \ldots$ \\
\hline S90 & 80,1859236 \\
\hline \multicolumn{2}{|c|}{$\sum$ Si $\mathbf{~} \mathbf{7 0 6 7 , 0 2 3 0 8 2 0}$} \\
\end{tabular}

3.6. Menghitung Nilai Vector (V)

Setelah mendapatkan nilai Vektor (S) langkah selanjutnya yaitu menentukan Nilai vector (V) dengan rumus:

$$
\begin{aligned}
& V 1=\frac{81,8774167}{7067,0230820}=0,0115858 \\
& V 2=\frac{70,3764743}{7067,0230820}=0,0099584 \\
& V 3=\frac{80,1872205}{7067,0230820}=0,0113467 \\
& V 4=\frac{75,5707893}{7067,0230820}=0,0106934 \\
& V 5=\frac{81,2914701}{7067,0230820}=0,0115029
\end{aligned}
$$

Untuk nilai V11 sampai dengan V90 dihasilkan dengan perhitungan yang sama, sehingga akan mendapatkan nilai V1 sampai dengan V90 pada Tabel 7.

Tabel 7. Preferensi Alternatif Vektor V

\begin{tabular}{|l|l|}
\hline Preferensi Alternatif & Nilai V \\
\hline V1 & 0,0115858 \\
\hline V2 & 0,0099584 \\
\hline V3 & 0,0113467 \\
\hline V4 & 0,0106934 \\
\hline V5 & 0,0115029 \\
\hline$\ldots \ldots$ & $\ldots \ldots$ \\
\hline V90 & 0,0113465 \\
\hline
\end{tabular}




\subsection{Menentukan Hasil}

Setelah semua tahap dilakukan kemudian dicari nilai terbesar, karena berdasarkan perhitungan dengan metode Weighted Product (WP) nilai terbaik adalah nilai terbesar dari semua alternative.

Tabel 8. Ranking Nilai Alternative

\begin{tabular}{|c|c|}
\hline Nilai & Alternatif \\
\hline 0,0127736 & A30 \\
\hline 0,0127474 & A21 \\
\hline 0,0127059 & A54 \\
\hline 0,0124764 & A29 \\
\hline 0,0124283 & A14 \\
\hline$\ldots \ldots$ & $\ldots \ldots$ \\
\hline 0,0099031 & A86 \\
\hline
\end{tabular}

Maka sesuai dengan hasil perhitungan dengan metode Weighted Product pada Tabel 8, diperoleh 3 urutan nilai terbesar yaitu A30, A21 DAN A54.

\subsection{Perancangan dan Implementasi Sistem}

Gambar 4 di bawah ini menggambarkan tentang entitas yang terlibat dalam sistem ini, dimana terdapat 5 (Lima) entitas, yaitu kriteria, user, siswa, nilai siswa dan hasil penyeleksian.

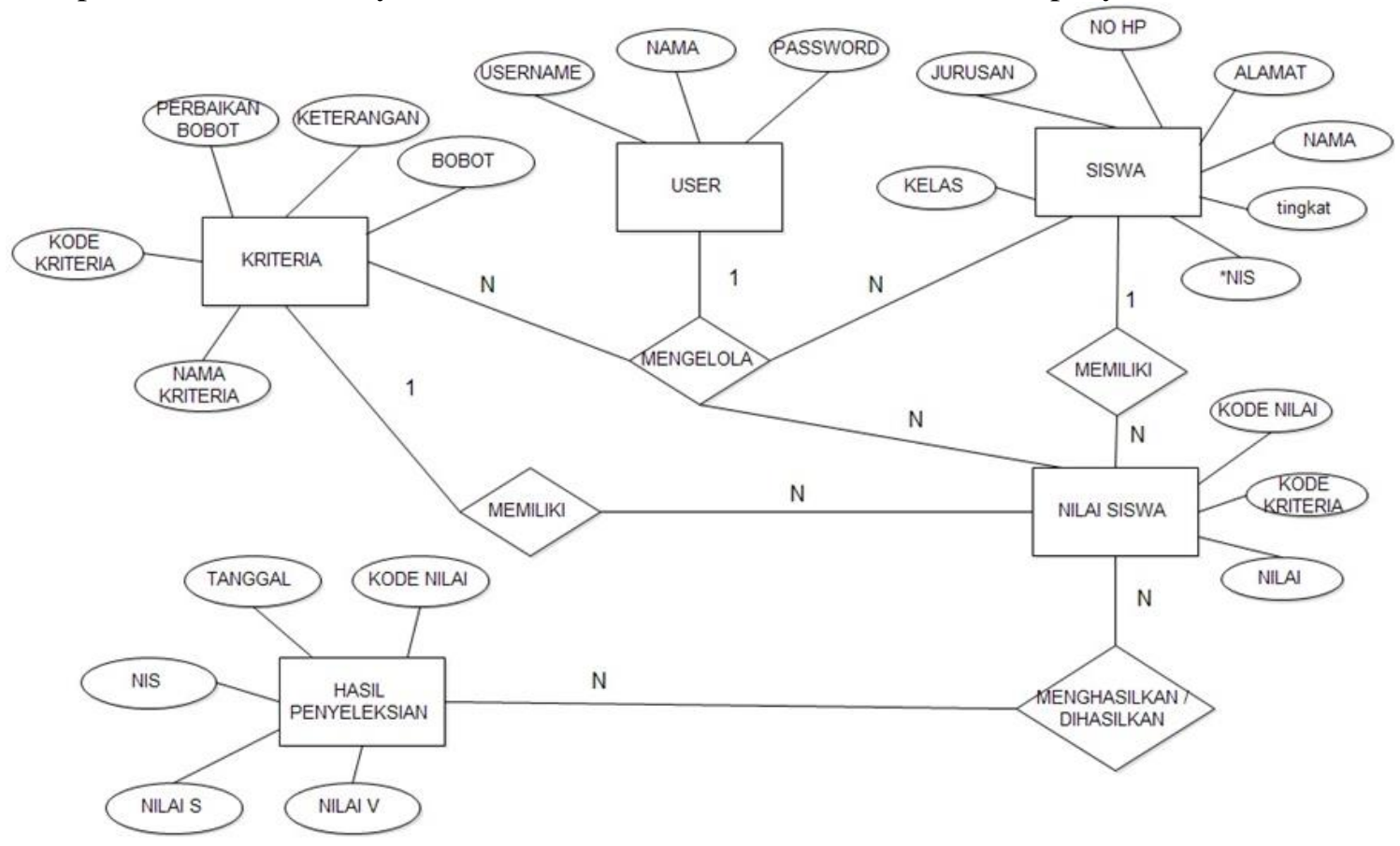

Gambar 4. Entity Relationship Diagram 
Citec Journal, Vol. 3, No. 4, Agustus 2016 - Oktober 2016

ISSN: 2460-4259

Gambar 5 di bawah ini menjelaskan tentang tabel yang terbentuk beserta relasinya. Dalam sistem ini terbentuk menjadi 4 tabel, yaitu tb_nilai, tb_hasil, tb_kriteria dan tb_siswa.

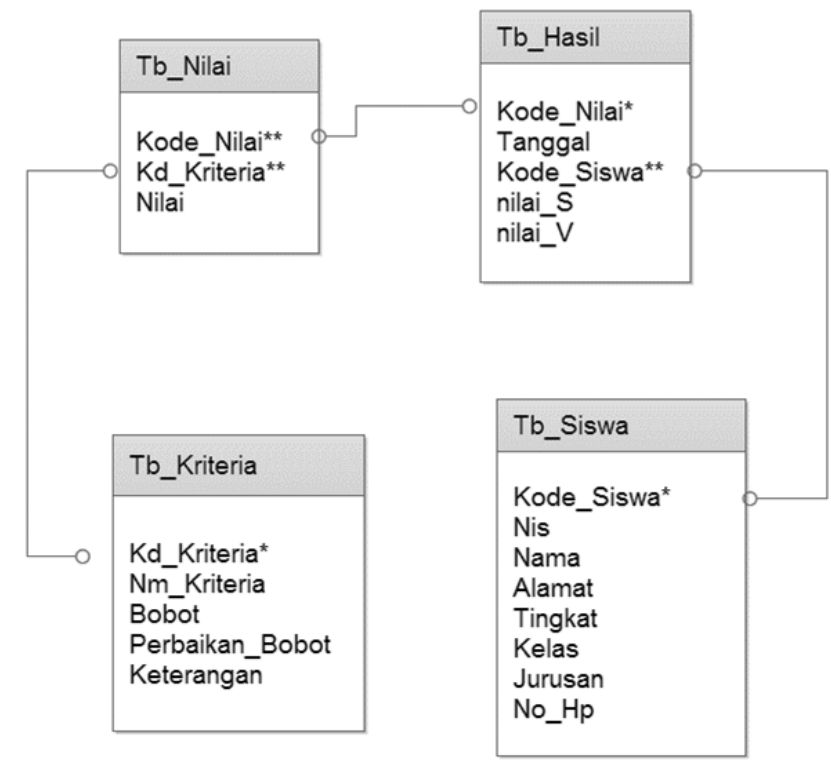

\footnotetext{
Ket: * Primary key

**Foreign Key
}

Gambar 5. Relasi Antar Tabel

Gambar 6 adalah gambaran Form Input data dan nilai siswa digunakan untuk menginputkan identitas dan nilai dari siswa yang mengikuti penyeleksian. Berikut Form Input data dan nilai siswa yang dipakai dalam aplikasi sistem pendukung keputusan penyeleksian siswa partner schulen der zukunft Tasikmalaya.

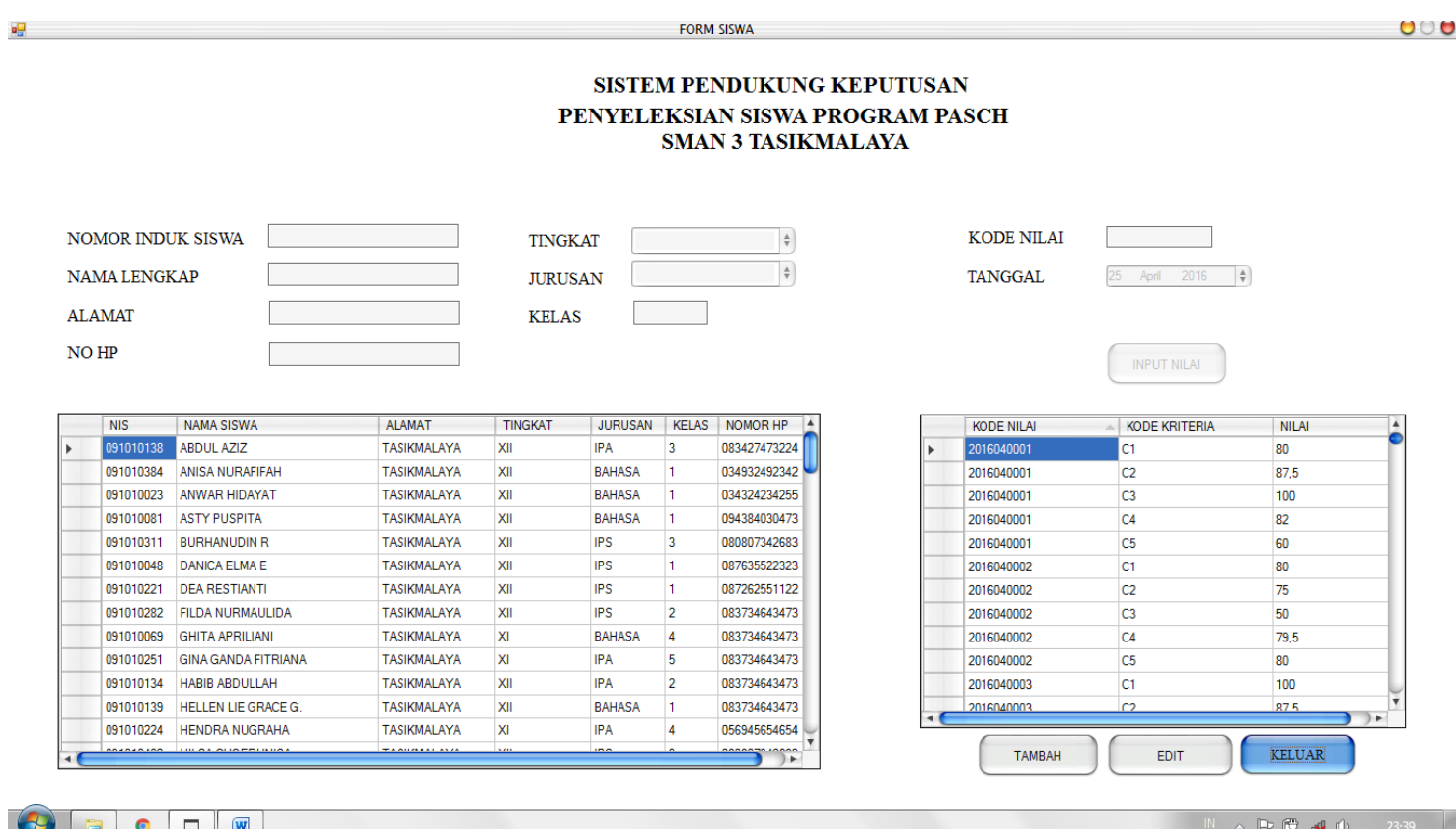

Gambar 6. Tampilan Form Input Data dan Nilai SIswa 
Gambar 7 menggambarkan form kriteria digunakan untuk menginputkan mengedit atau menghapus kriteria untuk penyeleksian yang digunakan pada periode tertentu. Berikut Form Kriteria yang dipakai dalam aplikasi sistem pendukung keputusan penyeleksian siswa partner schulen der zukunft Tasikmalaya.

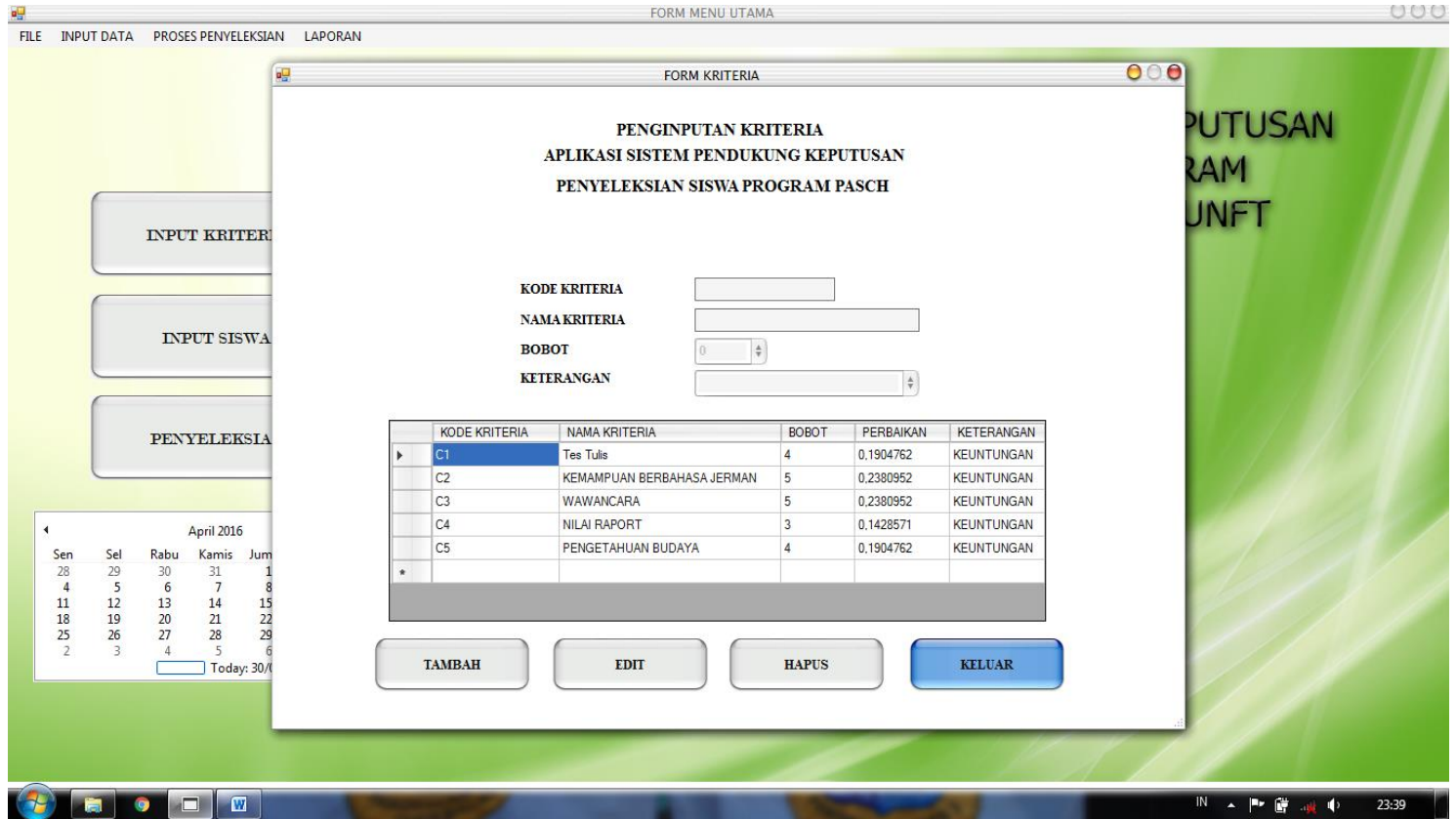

Gambar 7. Tampilan Form Kriteria

Gambar 8 menggambarkan penyeleksian digunakan untuk proses penyeleksian dengan metode Weighted Product. Berikut Form penyeleksian yang dipakai dalam aplikasi sistem pendukung keputusan penyeleksian siswa partner schulen der zukunft tasikmalaya.

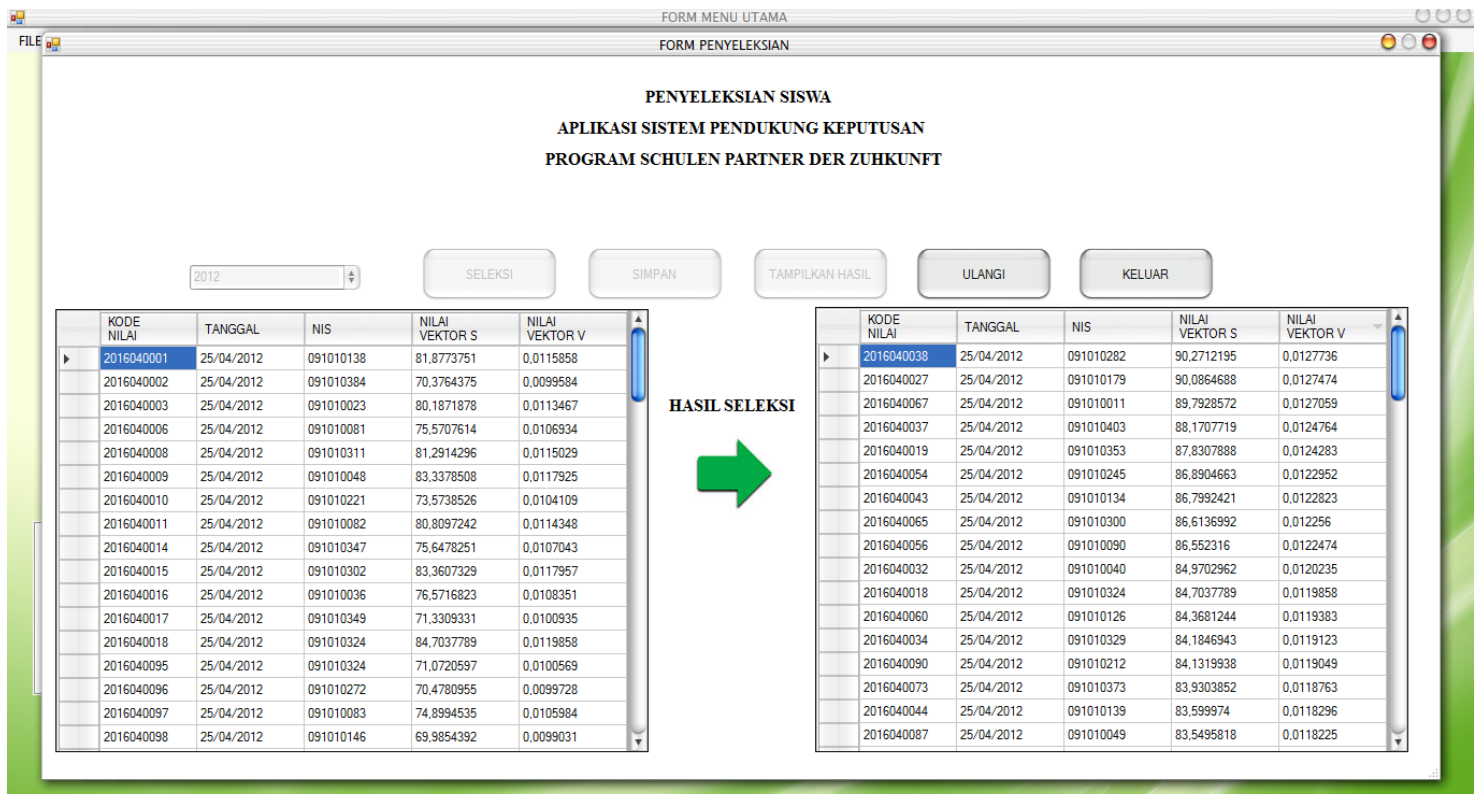

Gambar 8. Tampilan Form Penyeleksian 
Gambar 9 menggambarkan laporan hasil digunakan untuk melihat hasil penyeleksian dengan perhitungan metode Weighted Product yang dapat langsung di cetak untuk laporan hasil kepada kepala sekolah. Berikut Form Laporan hasil seleksi yang dipakai dalam aplikasi sistem pendukung keputusan penyeleksian siswa partner schulen der zukunft Tasikmalaya.

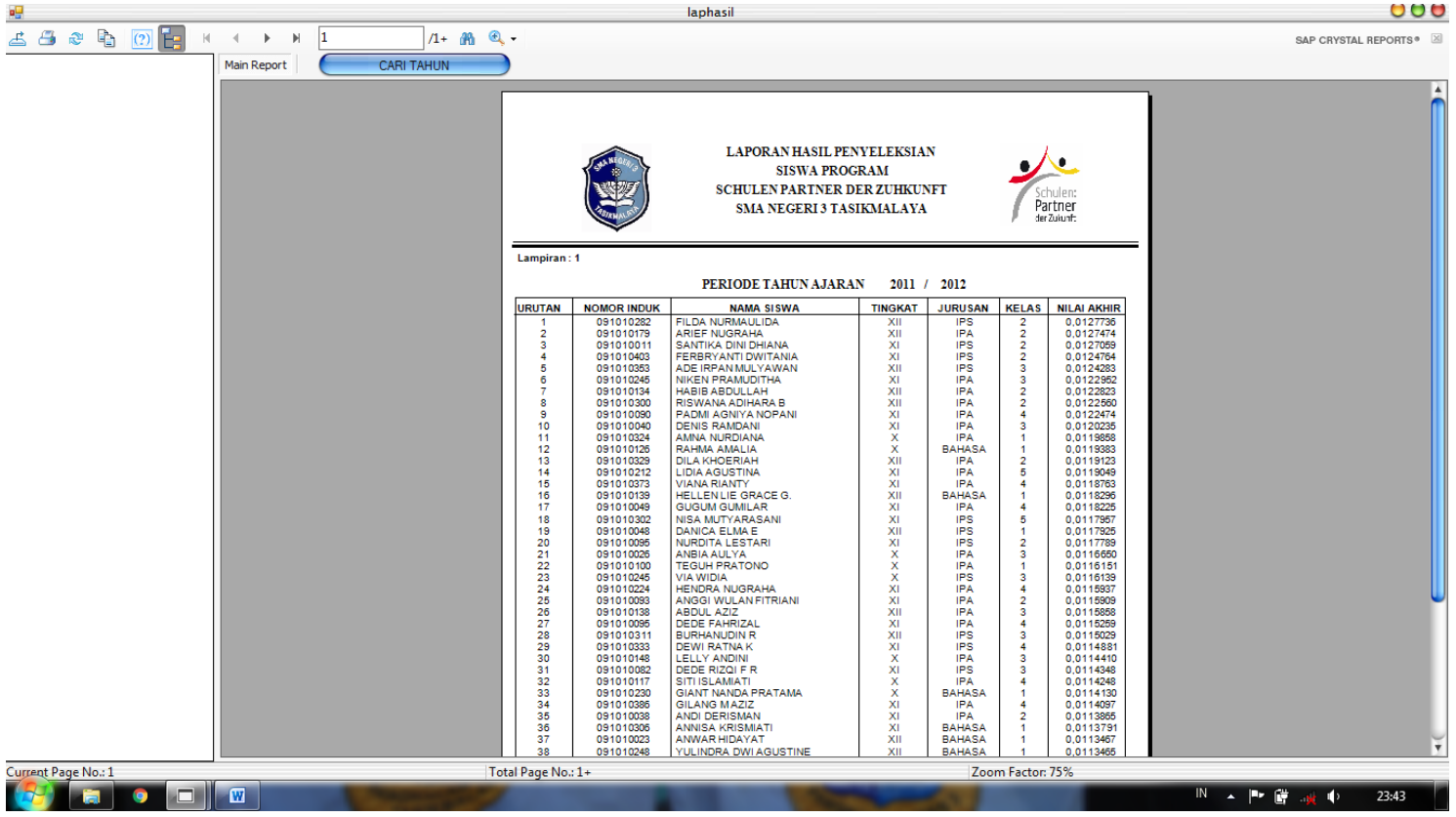

Gambar 9. Tampilan Form Laporan Hasil Penyeleksian

Dari tampilan Gambar 9 di atas, dapat diketahui hasil dari perhitungan dengan menggunakan metode Weighted Product, sehingga proses penyeleksian siswa partner schulen der zukunft di SMAN 3 Tasikmalaya dapat dilakukan dengan efektif dan efisien. Laporan ini akan dijadikan bahan pertimbangan oleh Kepala Sekolah dalam menetapkan siswa yang terpilih untuk mengikuti program siswa partner schulen der zukunft sesuai dengan kriteria yang telah ditentukan.

\section{KESIMPULAN}

berikut:

Dari hasil penelitian yang telah dilakukan, maka dapat diambil kesimpulan sebagai

1. Program Sistem Pendukung Keputusan penyeleksian siswa Program PASCH (PASCH) di SMAN 3 Tasikmalaya, dapat membantu sekolah dalam menghitung kelayakan calon penerima beasiswa belajar ke Jerman sehingga dalam proses perhitungan dan pelaporannya lebih cepat.

2. Dengan menerapkan metode Weighted Product dapat di terapkan dalam sistem pendukung keputusan penyeleksian PASCH di SMAN 3 Tasikmalaya sehingga meminimalisir ketidak tepatan hasil dan perhitungan menjadi lebih objektif.

3. Sistem yang dibuat hanya sebagai alat bantu untuk memberikan informasi kepada user sebagai bahan pertimbangan dalam mengambil keputusan 


\section{SARAN}

Dalam penelitian ini Peneliti menyarankan agar menambahkan fasilitas untuk backup database secara berkala untuk mengantisipasi keselamatan data jika terjadi kerusakan sistem. Kemudian dibuatkan pembatasan penginputan nilai sesuai dengan kebutuhan setiap kriteria yang diharapkan dengan adanya pengembangan terhadap program aplikasi ini dapat meningkatkan efisiensi kegunaannya dan melengkapi kekurangan-kekurangan yang ada.

\section{DAFTAR PUSTAKA}

[1] Hadi, S., 2012, Pembelajaran Bahasa Asing Di LPK CSBI, Tugas Akhir, Fakultas Bahasa Jepang, Universitas Widyatama, Bandung.

[2] Agustin, Y. H., Kurniawan, H., 2015, Sistem Pendukung Keputusan Penilaian Kinerja Dosen Menggunakan Metode Weighted Product (Studi Kasus: STMIK Pontianak), SNIF, Medan, 22 Agustus 2015.

[3] Pamungkas, F. D., 2014. Perancangan Sistem Pendukung Keputusan Seleksi Penerimaan Calon Bintara TNI AD dengan Menggunakan Metode Weighted Product. Informasi dan Teknologi Ilmiah (INTI). Vol. 4, No. 3

[4] Setyowulan, H., Kusrini, 2012, Sistem Pendukung Keputusan Penerimaan Pegawai Baru pada PT. Abadi Express (TIKI) Yogyakarta, Jurnal DASI, No. 1, Vol. 13, Hal 17-22.

[5] Lestari, S., 2013, Penerapan Metode Weighted Product Model Untuk Seleksi Calon Karyawan, Jurnal Sistem Informasi (JSI), No. 1, Vol. 5, Hal. 540-545.

[6] Munir, R., 2013, Metode Numerik, Penerbit Informatika Bandung, Bandung. 